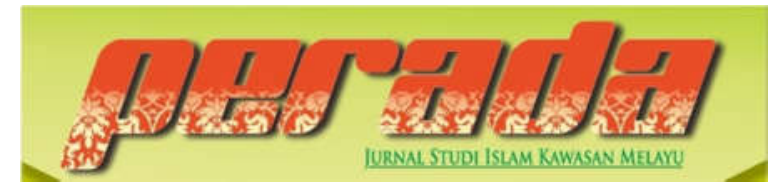

Perada: Jurnal Studi Islam Kawasan Melayu

ISSN 2656-7202 (P) ISSN 2655-6626 (0)

Volume 4 Nomor 1, Januari-Juni 2021

DOI: https://doi.org/10.35961/perada.v4i1.386

\title{
GAYA HIDUP MODERN PEREMPUAN MINANGKABAU AWAL ABAD KE-20
}

\author{
Febri Angraini \\ Universitas Andalas Padang Sumatera Barat \\ febriangraini@ymail.com
}

\begin{abstract}
ABSTRAK
Tulisan ini memuat gambaran umum modernitas dalam kehidupan perempuan Minangkabau di awal abad ke-20. Tahun 1900 hingga 1942 adalah gambaran umum modernitas dalam kehidupan perempuan yang dimaksud. Pemerintahan Hindia Belanda telah membawa masuk gaya pemikiran barat, yang di antaranya disalurkan lewat pendidikan. Politik Etis memudahkan jalan modernisasi untuk membuka ruang. Perubahan demi perubahan terjadi dalam gaya hidup perempuan Minangkabau. Proses kritik dalam upaya meninggalkan gaya hidup konvensional dibawa oleh tokoh-tokoh perempuan Minangkabau yang berjasa dalam dunia pendidikan. Mereka mengupayakan perubahan dalam sistem adat yang konvensional dan dinilai merugikan perempuan. Perilaku gaya hidup modern pun kemudian terjadi dalam keseharian perempuan Minangkabau. Modernitas di Minangkabau adalah gabungan nilai-nilai adat tradisional, pengaruh Islam dan pengaruh barat yang memberi dampak dalam berbagai aspek dalam masyarakat Minangkabau. Dampak dalam modernitas di Minangkabau, dari segi positif yaitu membawa pemabaharuan dalam pendidikan bagi kaum perempuan, sementara dampak negatifnya, perselisihan kaum tua dan kaum muda, hingga munculnya kebiasaan-kebiasaan yang didasarkan atas nama tren semata.
\end{abstract}

This paper contains a general description of modernity in the lives of Minangkabau women in the early 20th century. The years 1900 to 1942 were a general description of modernity in the life of the intended woman. The Dutch East Indies government has brought the Western style of thinking through education. Ethical Politics facilitates the way of modernization to open up and change the lifestyle of Minangkabau women. The process of criticism as an effort to leave the conventional lifestyle was brought by Minangkabau women who contributed in the world of education. They seek changes in conventional custom systems. Modern lifestyle behavior then occurs in the daily life of Minangkabau women. Modernity in Minangkabau is a combination of traditional, Islamic, and western values affecting various aspects in Minangkabau society. The impact on modernity in Minangkabau, from a positive aspect, is to bring a breakthrough in education for women, while the negative impact is the dispute of the elderly and young people and the emergence of habits following the trends.

Kata Kunci : perempuan modern, minangkabau, adat 


\section{PENDAHULUAN}

Periode awal abad ke-20 diambil sebagai acuan waktu munculnya generasi tokoh modern Minangkabau yang mempunyai banyak peran dalam memperjuangkan kemerdekaan Indonesia. Penggunaan istilah modern dan konvensional bukanlah dimak-sudkan untuk membandingkan. Adapun pemakaian kedua istilah tersebut berguna untuk pemetaan atau penggambaran situasi kehidupan perempuan Minangkabau sebelum dan ketika memasuki abad ke-20. Istilah modern dalam tulisan ini merujuk pada perubahan yang terjadi dalam kehidupan perempuan ketika memasuki abad ke-20. Perubahan-perubahan yang terjadi menyebabkan perubahan gaya hidup dari yang lama ke yang baru, dari konvensional ke modern. Faktor-faktor perubahan berasal dari berbagai aspek penunjang kehidupan seperti, aspek ekonomi, sosial, budaya, dan politik.

Masuknya pengaruh atau nilai baru dalam masyarakat, tidak hanya akan mengubah satu atau dua hal yang berhubungan langsung dengan pengaruh atau nilai tersebut, nyatanya banyak hal yang akan berubah. Sumatra's Westkust adalah nama salah satu wilayah di Hindia Belanda yang sebagian besar penduduknya merupakan orang Minangkabau. Pada awal abad ke-20 banyak sekali di wilayah ini didirikan sekolah-sekolah modern sebagai perwujudan Politik Etis. Sejalan dengan ini, pada awal abad ke-20 juga adalah masa bermunculan tokoh-tokoh politik yang vokal dalam menyuarakan kemerdekaan. Sejumlah partai politik sebagai wadah pergerakan mereka saat itu, banyak sekali bermunculan di dalam wilayah Sumatra's Weskust.

Beberapa organisasi politik ataupun organisasi yang turut berjuang melawan penjajahan yaitu, Permi (Persatuan Muslimin Indonesia), PSII, dan Jong Sumatranen Bond. Berbagai macam upaya dilakukan sebagai bentuk gerakan untuk lepas dari penjajahan. Banyaknya upaya-upaya yang dilakukan, sejalan dengan terjadinya banyak pembaharuan yang terjadi dalam ruang lingkup adat Minangkabau. Apa yang dulu dianggap sebagai bagian dari tabu, kemudian menjadi hal yang dibiasakan untuk dikerjakan. Salah satu bentuk pembaharuan adalah gaya hidup perempuan Minangkabau.

Sebelum memasuki abad ke-20, perempuan sangat lekat dengan urusan domestik. Kedudukan mereka dalam adat sudah diatur sebagai pemegang harta pusaka, salah satunya menjaga Rumah Gadang. Akses pendidikan yang disediakan oleh Pemerintah Kolonial Belanda membuka jalan bagi perempuan Minangkabau untuk bisa masuk ke dunia politik, sosial, budaya, ekonomi. Mereka diberi ruang baru yang lebih luas dari hanya sekedar menjalankan fungsi perempuan dalam tatanan adat. Gaya pemikiran baru kemudian mengubah gaya hidup mereka. Mereka mulai aktif dan mempunyai peran baru dalam tatanan masyarakat.

Kendati demikian, perjuangan kaum perempuan Minangkabau dalam menjalani gaya hidup modern banyak mendapat tantangan dan rintangan dari lingkungan mereka sendiri. Sebelum masuknya pendidikan modern, perempuan Minangkabau haruslah bersikap tunduk terhadap semua peraturan adat. Dari urusan kegiatan sehari-hari hingga urusan penting seperti pernikahan, telah diatur oleh adat. Anak perempuan yang telah memasuki usia pubertas dijaga ketat oleh keluarganya. Setelah menikah dengan pasangan yang dipilihkan oleh keluarga, kegiatan mereka masihlah dipusatkan di kegiatan domestik. Adapun kegiatan ekonomi yang mereka lakukan adalah 
kegiatan yang sederhana yaitu berdagang di pasar-pasar nagari. ${ }^{1}$

Reni Nuryanti menjelaskan gambaran perempuan Minangkabau secara umum yang ia ringkas seperti kutipan berikut ini.

"Secara ringkas, terdapat enam prinsip
utama dari adat Minangkabau yang
bersendikan sistem kekerabatan
matrilineal. Keenam prinsip tersebut
adalah: (i) pibak. yang melabirkan anak
dan yang memiliki anak adalah
perempuan (ibu/mande); (ii) pihak yang
memiliki kuasa terbadap dan wewenang
terbadap kaum perempuan dan anak-
anak (anak buah) adalah laki-laki
(mamak, datuk, dan pengbulu); (iii)
keturunan ditarik dan ditelusuri melalui
garis perempuan; (iv) anggota kelompok
keturunan (suku, payuang, paruik,
kampuang, dan rumah gadang)
diangkat dan direkrut melalui garis
perempuan; (v) pewarisan harta pusaka,
rumah gadang, gelar, kedudukan dan
kekuasaan politik dilaksanakan
melalui garis perempuan; dan (vi)
perkawinan didasarkan pada eksogami
kelompok, bukan pada endogami
kelompok.",

Meskipun sebagian besar poin di atas menguntungkan perempuan, tapi, kekuasaan perempuan pada praktiknya tidak bisa dikatakan menguntungkan. Pada poin (ii) tertera bahwa laki-laki memiliki kekuasaan terhadap perempuan. Di poin (v) disebutkan pewarisan harta pusaka, rumah gadang, gelar, kedudukan dan kekuasaan politik dilaksanakan melalui garis perempuan. Perlu digarisbawahi di sini, secara praktek, perempuan Minangkabau cenderung tidak punya

\footnotetext{
${ }^{1}$ Risa Marta Yanti, 'Labirnya Pergerakan Perempuan Minangkabau Pada Awal Abad XX', Jurnal Kafaah, 7.2 (2018).

${ }^{2}$ Reni Nuryanti, Perempuan Berselimut Konflik, Perempuan Minangkabau di Masa Dewan Banteng dan PRRI (Yogyakarta: Tiara Wacana, 2011), h. 25
}

kuasa. Pun pada poin (vi), sudah jelas apakah itu endogami atau eksogami, perkawinan mereka sudah ditentukan oleh pihak yang mempunyai kuasa atas diri mereka.

Dunia Minangkabau pada awal abad ke-20 sarat dengan gerakan-gerakan yang berdasarkan pada intelektualitas sebagai bentuk kritikan terhadap kemapanankemapanan yang telah lama ada. ${ }^{3}$ Para kaum perempuan mengkritisi ketidakadilan yang mereka terima selama ini. Pendidikan barat yang sering dicitrakan negatif, nyatanya juga membuka jalan untuk mereka agar mampu melihat akar permasalahan dari kacamata lain. ${ }^{4}$ Selain itu pengaruh dari pendidikan berlandaskan Islam juga turut serta berperan dalam pergerakan kaum perempuan. Salah satu tokoh yang memajukan kaum perempuan dari segi pendidikan Islam adalah Rahmah El Yunusiah.

Tantangan yang mereka hadapi tentu tidak mudah. Perombakan berbagai hal dalam kehidupan perempuan Minangkabau awal abad ke-20 tentu mendapat semjulah hambatan. 'Mengubah' kebiasaan selama ini dan mengkritisinya, secara logika, pasti banyak yang akan menentang. Belum lagi, nilai-nilai modern yang dimaksud tidak sepenuhnya bisa diterima begitu saja, apalagi diaplikasikan dengan mudah. Perlu ditilik lagi apa sebenarnya yang dimaksud dengan modern oleh kaum perempuan Minangkabau pada awal abad ke-20.

Tulisan ini dibuat untuk mengupas gaya hidup modern orang Minangkabau, khususnya pada kaum perempuan. Kata "modern" sangat lekat dalam kehidupan masyarakat Minangkabau di awal abad ke20. Modern sering sekali dikaitkan dengan

3 Yelda Syafrina, Minangkabau dalam Kemoderenan 1900-1942 (Tesis. Universitas Gadjah Mada, 2015), h. 2.

4 Thung Ju Lan, 'Perempuan dan Modernisasi', Jurnal Masyarakat dan Budaya, 17.1 (2015). 
gaya hidup yang kebarat-baratan. Gaya hidup modern pun sering dijadikan lawan dari gaya hidup konvensional (gaya hidup sesuai dengan aturan adat Minangkabau). Untuk mempermudah melihat permasalahan, maka dilakukan pembagian ke dalam beberapa poin; Apa yang dimaksud dengan gaya hidup modern perempuan Minangkabau awal abad ke-20? Dan bagaimana dampak gaya hidup modern pada perempuan Minangkabau secara umum?

Sesuai dengan dua poin di atas, maka tahun pembahasan akan dibatasi dari 1900 sampai 1942. Pembatasan pada tahun 1942, dikarenakan pada tahun ini, Jepang telah masuk dan menguasai Indonesia. Tentu saja jika pembahasan dalam tulisan melampaui tahun 1942, akan memperlebar masalah yang dibahas sehingga tidak fokus pada benang merah yang dimaksud. "Modern" dalam tulisan ini menitikberatkan ketika masuknya pendidikan barat yang dipengaruhi Pemerintah Hindia Belanda pada awal abad ke-20. Tulisan ini dibuat untuk mengetahui gerak gaya hidup modern perempuan Minangkabau pada awal abad ke-20. Diharapkan tulisan ini dapat memetakan kata "modern" dalam kehidupan perempuan Minangkabau secara umum.

Penelitian ini menggunakan metode sejarah yang mempunyai empat tahapan dalam proses pengerjaannya. Tahapan pertama adalah heuristik. Pada tahapan ini langkah yang dilakukan adalah pengumpulan sumber. Penelitian ini menggunakan sumber berupa buku, jurnal, artikel yang memuat informasi-informasi yang dibutuhkan. Kedua, adalah tahapan kritik. Pada tahapan ini sumber-sumber yang telah ditemukan harus diuji keakuratannya. Tahapan ketiga adalah penginterpretasian fakta-fakta yang telah diuji sebelumnya. Terakhir, adalah historiografi. Kegiatan untuk menghasilkan sebuah tulisan sejarah.

\section{ADAT MINANGKABAU, ISLAM, DAN BARAT}

Minangkabau adalah salah satu dari sedikit suku di dunia yang masih menggunakan formula matrilineal. Adat Minangkabau menempatkan perempuan sebagai pemegang kontrol terhadap harta pusaka. Dari peraturan ini terlihat bahwa perempuan sesungguhnya mempunyai kedudukan yang kuat dan diuntungkan oleh adat. Sementara laki-laki mempunyai kedudukan rapuh jika dibandingkan dengan perempuan. Setelah menikah, lakilaki tidak mempunyai kuasa di rumah istrinya. Ia masihlah merupakan bagian dari keluarga Ibunya. Anak dan istri dari seorang laki-laki bukanlah merupakan tanggung jawabnya melainkan tanggung jawab Mamak dari keluarga istri. ${ }^{5}$

Realitas adat yang demikian kemudian menyebabkan terjadinya Perang Paderi. Kaum Paderi yang menuntut pemurnian Islam di dalam aturan adat, termasuk di dalamnya porsi laki-laki yang harus lebih besar untuk berperan dalam tanggung jawab kepada anak dan istrinya dibandingkan dengan peran seorang Mamak. ${ }^{6}$ Semenjak terjadinya perselihan Kaum Paderi dan Kaum Adat pada 1830an ini, terjadi kombinasi baru dalam aturan adat. Di mana Islam dan adat melahirkan sebuah nilai-nilai baru dalam kehidupan masyarakat.

Pada tahun 1837, wilayah Sumatera Barat dimasukan ke dalam wilayah pemerintahan Hindia Belanda dengan nama Gouvernement Sumatra's Westkust. Pengaruh barat, pengaruh Islam dan adat

5 Taufik Abdullah, 'Adat and Islam ; an Examination of Conflict in Minangkabau', Southeast Asia Program Publications at Cornell University, 2 (1966)

6 Yelda Syafrina, Minangkabau dalam Kemodernan 1900-1942 (Tesis. Universitas Gadjah Mada, 2015), h. 32

${ }^{7}$ Gusti Asnan, 'Transportation on the west cost of Sumatra in the nineteenth century', BRILL. 158.2 (2002) 
tradisional kemudian membentuk suatu arah baru dalam kehidupan masyarakat Minangkabau baik itu dalam bentuk pembangunan fisik ataupun non-fisik. Pembangunan fisik salah satunya, yang bisa dilihat dalam bidang transportasi, seperti yang dikutip dari tulisan Gusti Asnan berikut ini.

"West Sumatra was known as one of the few regions outside Java that had a considerable number of autombiles. The total number of automobiles in West Sumatra in the early 1920s was estimated at more than 3,000 and by the late 1920s it had more than doubled to 7,000...*

Islam juga telah memberikan warnanya sendiri dalam adat. Surau adalah salah satu bentuknya. Pada fungsinya sebagai bagian dari pembangunan nonfisik, surau selain digunakan untuk tempat beribadah juga digunakan sebagai tempat untuk mendapatkan ilmu. Bahkan sebelum Perang Paderi, surau telah memberikan fungsinya bagi masyarakat sebagai tempat pendidikan. Berikut kutipan untuk penjelasan tersebut.

"The study of fikh took place in the Islamic schoos or surau of the leading Sufi brotherhood in Agam, the Syattariah, and was accepted as part of the course of instruction side by side with the traditional emphasis on mystical knowledge and devotion. One reason for this was the main suran were never cut off from the life of the society around them. With the general increase in prosperity they began to attract far greater numbers of students, all of whom were required to finance what was often a very protracted period of learning."

Sebelum tersedia banyaknya sarana pendidikan formal seperti yang terjadi pada abad ke-20, surau merupakan sarana pendidikan yang penting bagi masyarakat

\footnotetext{
${ }^{8}$ Ibid.

9 Christine Dobbin, 'Economic Change in Minangkabau as a Factor in the Rise of the Padri Movement, 1784-1830', Southeast Asia Program Publications at Cornell University. 23 (1977) 28.
}

Minangkabau. Surau adalah salah satu perwujudan dari akulturasi antara adat dan Islam. Azyumardi Azra menjelaskan bahwa seorang pejabat Belanda bernama Verkerk Pistorious, pernah menelaah surau dan dari penjabarannya, ia membagi surau ke dalam tiga kategori. Pertama, surau kecil yang menampung sampai 20 murid. Kedua, surau sedang untuk 80 murid. Ketiga, surau besar antara 100 hingga 1000 murid. $^{10}$

Eksistesi surau sebagai sarana pendidikan mulai memudar di awal abad ke-20. Pemerintah Hindia Belanda mulai banyak mendirikan sekolah untuk pribumi. Dari sini kemudian pemikiran-pemikiran barat banyak memberikan pengaruh dalam masyarakat. Gagasan-gagasan bergaya barat atau juga bisa disebut modern, banyak mendapat pertentangan dari beberapa kelompok dalam masyarakat. Kelompok yang menentang salah satunya berasal dari kaum ulama tradisional. Anggapan mereka, gagasan ataupun pemikiran modern (pengaruh barat) tidak sesuai dengan konsep Minangkabau yang telah lama ada. ${ }^{11}$

\section{PEREMPUAN MINANGKABAU DI ERA KOLONIAL (AWAL ABAD KE- 20)}

Walaupun keberadaan Belanda di Indonesia telah ada jauh sebelum tahun 1900 tapi, secara rata-rata, kekuasaan Belanda baru menyeluruh dari segi militer dan administratif pada tahun tersebut. Perubahan di wilayah kolonial Hindia Belanda mulai terlihat dari berbagai aspek; ekonomi, sosial, budaya. Nilai-nilai tradisional bersinggungan dengan nilainilai barat. ${ }^{12}$ Masuknya nilai-nilai barat ke

10 Meimunah Moenada, 'Surau dan Modernisasi Pendidikan di Masa Hindia Belanda', Jurnal Sosial Budaya. 8.1 (2011)

${ }^{11}$ Ibid.

12 Elsbeth Locher-Scholtten, Woman and the Colonial State Essays on Gender and Modernity in the Netherlands Indies 1900-1942 (Amsterdam: Amsterdam University Press, 2000), h. 16 
dalam kehidupan tradisional, secara umum dapat diartikan sebagai modernisasi. Akan tetapi, seringkali modernisasi juga diartikan sebagai westernisasi, yang mana dua hal tersebut mempunyai pengertian yang berbeda. Westernisasi adalah sikap meniru dan menerapkan budaya barat tanpa adanya penyeleksian serta penyesuaian dengan nilai-nilai yang telah dimiliki. ${ }^{13}$

Pengaruh barat atau modernisasi dalam masyarakat Minangkabau bisa dilihat salah satunya melalui perkembangan pendidikan. Politik Etis membuka jalan baru dalam arah perkembangan pendidikan di Minangkabau. Pendidikan modern ini kemudian dimanfaatkan oleh kaum perempuan sebagai strategi dasar dalam memperjuangkan nasib mereka yang selama ini didomestifikasi oleh aturanaturan adat. Perlu ditekankan di sini, pengertian domestifikasi bukan sebatas perempuan dengan pekerjaannya dalam rumah tangga. Domestifikasi di sini adalah ruang gerak perempuan yang dibatasi untuk kegiatan-kegiatan tertentu.

Perempuan yang punya kemampuan membaca dan menulis adalah hal langka yang jarang ditemui pada awal abad ke-20. Mereka yang bisa menikmati pendidikan adalah mereka yang berasal dari kalangan tertentu. Anak-anak perempuan yang menikmati keistimewaan untuk bersekolah adalah mereka yang para orangtuanya berstatus sebagai pegawai pemerintah kolonial seperti guru, jaksa, dan pegawai gudang kopi. ${ }^{14}$ Kenyataan inilah yang mendorong lahirnya sejumlah gerakan perempuan untuk memajukan kaumnya. Dari pendidikan yang mereka dapatkan di sekolah, mereka tahu bahwa keberadaan

13 Thung Ju Lan, 'Perempuan dan Modernisasi', Jurnal Masyarakat dan Budaya, 17.1 (2015).

${ }^{14}$ Risa Marta Yanti, 'Labirnya Pergerakan Perempuan Minangkabau Pada Awal Abad XX', Jurnal Kafaah, 7.2 (2018). mereka selama ini dalam masyarakat cenderung dirugikan.

Kolonial menyumbang sejumlah masalah patriarki kepada para perempuan pribumi di Hindia Belanda. Di sisi lain, lewat pendidikan barat yang diterima para perempuan pribumi, mereka mengetahui bahwa di Eropa sana, sedang berlangsung gerakan-gerakan melawan patriarki. Pengetahuan tersebut kemudian ikut menyebar dan membakar semangat perempuan pribumi di Hindia Belanda untuk melakukan hal serupa. Dari Minangkabau sendiri lahir sejumlah tokoh perempuan yang melakukan gerakan melawan ketidakadilan. Rohana Kudus dan El Rahmah Junusiah adalah dua orang di antara beberapa tokoh perempuan dalam dunia pendidikan Minangkabau.

$$
\text { Rohana Kudus merupakan }
$$

wartawan perempuan pertama di Indonesia. Ia lahir di Koto Gadang dengan nama Siti Rohana pada 20 Desember 1884. Pada tahun 1912, Rohana Kudus dan pemimpin redaksi Oetosan Melajoe, Datuk Sutan Maharadja mendirikan Soenting Malajoe. Rohana adalah anak dari seorang Hoofd Djaksa (Kepala Jaksa). ${ }^{15} \mathrm{Di}$ usia 8 tahun Rohana sudah bisa membaca dan menulis, terutama huruf latin. Kepandaian ini ia dapatkan dari ibu angkatnya bernama Adiesa, yang juga mengajari Rohana berbahasa Belanda. ${ }^{16}$

Dibanding dengan anak perempuan lain seusianya, Rohana bisa dikatakan cukup beruntung. Tidak banyak anak kecil apalagi perempuan yang bisa membaca dan menulis. Kesadaran Rohana dalam kenyataan inilah yang kemudian

\begin{tabular}{l}
\hline 15 'Pahlawan Perempuan dari $\begin{array}{r}\text { Tanah } \\
\text { Historia }\end{array}$ \\
$\begin{array}{l}\text { Minang', } \\
\text { <https://historia.id/search/result?keyword=Roha }\end{array}$ \\
$\begin{array}{l}\text { na\%20kudus\&current=topic\&page=1> } \\
\text { July 2020). }\end{array}$ \\
16 Nur Janti, 'Perjuangan 11 \\
$\begin{array}{l}\text { Pendidikan Rohana dalam } \\
\text { <https://historia.id/kultur/articles/perjuangan- }\end{array}$ \\
$\begin{array}{l}\text { rohana-dalam-pendidikan-kaumny-Pdle3> (acsess } \\
\text { 11 Juli 2020) }\end{array}$
\end{tabular}


mengantarkannya menjadi pejuang untuk kaumnya, khususnya di Minangkabau. Anak perempuan cenderung tidak diutamakan dalam pendidikan. Rohana kemudian mendirikan Kerajinan Amai Setia (KAS) pada 11 Februari 1911. ${ }^{17}$

Kerajinan Amai Setia mengajarkan kepandaian menulis, membaca serta keterampilan untuk menyulam dan menjahit bagi para perempuan. Tidak ada batasan umur di dalam KAS. Hal ini terbukti, para perempuan yang belajar di KAS berasal dari usia yang beragam, dari yang muda hingga para ibu rumah tangga. Di tahun 1917, Rohana Kudus mendirikan Rohana School di Bukittinggi. Rohana Kudus mendedikasikan hidupnya untuk memajukan kaum perempuan, khususnya dalam pendidikan.

Selain Rohana Kudus, tokoh lain yang juga berpengaruh pada awal abad ke20 adalah Rahmah El Junusiyah. Jika Rohana Kudus fokus pada pengembangan pendidikan perempuan dalam membaca, menulis, serta beberapa keterampilan lainnya, maka Rahmah El Junusiyah fokus dalam pengembangan pendidikan Islam. Rahmah El Junusiyah lahir pada tahun 1900. Ia lahir dari keluarga ulama yang progresif. Ayahnya adalah Syekh Muhammad Yunus, seorang qaddi di Pandai Sikat. Sementara itu kakaknya merupakan ulama muda revolusioner bernama Zainuddin Labay El Yunusy, yang mengubah sekolah agama menjadi sekolah modern, dan memperbolehkan laki-laki dan perempuan untuk bersekolah di tempat yang sama. Rahmah pernah bersekolah di tempat ini. ${ }^{18}$

Pada tahun 1923 Rahmah El Junusiyah mendirikan Al Marasatud

${ }_{17}$ Risa Marta Yanti, 'Labirnya Pergerakan Perempuan Minangkabau Pada Awal Abad XX', Jurnal Kafaah, 7.2 (2018)

18 Nur Janti, 'Kala Ulama Perempuan

Melawan', Historia

$<$ https://historia.id/search/result?keyword=Ulam $\mathrm{a} \% 20$ perempuan\&current $=$ topic\&page $=1>$ (acsess 11 Juli 2020)
Dinijjah Lil Banaat yang merupakan cikal bakal dari Dinnijah School Puteri, sekolah modernis Islam pertama di Hindia Belanda. Selain itu Rahmah juga membuka Sekolah Menyesal. Jumlah pelajar perempuan yang mengikuti pendidikan di sekolah ini sebanyak 125 orang. Di sekolah ini juga diajarkan membaca, menulis, serta berhitung. Para murid atau pelajarnya berasal dari para anak-anak muda hingga ibu-ibu. ${ }^{19}$

\section{GAYA HIDUP MODERN DALAM KEHIDUPAN SEHARI-HARI}

Pembahasan mengenai kehidupan sehari-sehari masih sering digolongkan sebagai hal yang remeh. Penyebabnya, karena kegiatan sehari-hari yang dilakukan rutin diaggap sebagai kegiatan yang tidak penting. Padahal gaya hidup sehari-hari adalah cerminan banyak peristiwa dalam sejarah. Pengaruh pergerakan atau peristiwa dalam suatu masa dengan gaya hidup kehidupan sehari-sehari di masa itu, akan saling mempengaruhi satu sama lain.

Sejarah kehidupan sehari-hari adalah kajian mengenai kelompok subaltern. Periode kolonial di Indonesia bisa digolongkan kepada sejarah mengenai kelompok sulbatern, mengenai mereka yang terjajah. ${ }^{20}$ Perempuan di dalam tulisan ini bisa dimasukan sebagai kelompok subaltern. Mereka adalah kelompok dalam masyarakat di Hindia Belanda yang mengalami penjajahan dua kali baik itu yang dilakukan oleh pihak kolonial maupun oleh adat.

Perempuan sebagai bagian dalam masyarakat adalah kelompok yang posisinya paling rentan. Eksistensi mereka sebagai manusia dalam masyarakat seringkali perlu dipertanyakan. Misalnya

${ }^{19}$ Risa Marta Yanti, 'Labirnya Pergerakan Perempuan Minangkabau Pada Awal Abad XX', Jurnal Kafaah, 7.2 (2018)

20 Yelda Syafrina, Minangkabau dalam Kemodernan 1900-1942 (Tesis. Universitas Gadjah Mada, 2015), h. 15-16 
saja dalam berkarya, berkarir, atau yang lainnya, perempuan selalu membiasakan diri untuk memperkenalkan diri mereka sebagai seorang perempuan; I am a woman. Berbeda dengan laki-laki, kebanyakan dari mereka tidak perlu repot-repot untuk melakukan hal ini. Keberadaan mereka diakui dalam masyarakat dan tidak butuh pernyataan untuk memperkenalkan diri. ${ }^{21}$

Gaya hidup sehari-hari juga masih seringsekali dipersempit maknanya menjadi kegiatan yang hanya sekedar makan, mandi, melakukan pekerjaan rumah dan sebagainya. Kenyataannya makna dari gaya hidup sehari-hari adalah pemahaman terhadap masyarakat; para pekerja, orang-orang miskin, dan kelompok-kelompok lainnya yang berjuang dalam berbagai situasi yang ada. Mereka yang yang berjuang ini bergelut di dalam kesempatan, komunitas, agama, produksi, repoduksi dan sebagainya. ${ }^{22}$

Modernisasi membawa pengaruh dalam kehidupan perempuan di awal abad ke-20. Semangat untuk menggali intelektualitas pada masa tersebut berdampak pada berbagai aspek dalam kemasyarakatan. Pengaruh ini berdampak pada gaya hidup perempuan Minangkabau. Mereka masuk dalam modernitas, ke dalam semangat untuk mengkritisi dan memperbaharui apa yang seharusnya diperbaharui.

Kegiatan sehari-hari perempuan Minangkabau sudah diatur menurut adat. Mereka mendapatkan peran yang mana pelaksanaannya harus diterapkan dalam porsi yang pas, tidak boleh kurang dan tidak boleh lebih. Siklus hidup mereka adalah menjadi ibu yang bertanggung jawab untuk mengurusi anak-anaknya,

21 Simone De Beauvoir, The Second Sex, trans. by Constance Borde \& Sheila MalovanyChevallier (New York: Vintage Book a Division of Random House, Inc, 2010), h. 25

22 Yelda Syafrina, Minangkabau dalam Kemodernan 1900-1942 (Tesis. Universitas Gadjah Mada, 2015), h. 16 sebagai penjaga harta pusaka, pendidikan yang mereka terima hanya sebatas pendidikan keagamaan, kegiatan ekonomi yang mereka lakukan adalah jenis ekonomi pedesaan yaitu mengurusi sawah dan ladang. Pada kegiatan ekonomi ini, mereka juga mempunyai tanggung jawab untuk memasarkannya. Karenanya banyak perempuan yang menjadi pedagang di pasar-pasar nagari. Pun di pasar ini para perempuan juga berdagang hasil kerajinan tangan yang mereka buat. ${ }^{23}$

Pada penghujung abad ke-19 ketika pengaruh barat telah masuk ke dalam Minangkabau, pembatasan terhadap aktivitas perempuan terlihat jelas. Laki-laki boleh bersekolah, sementara perempuan tabu untuk bersekolah. Mereka tetap dituntut untuk mematuhi peraturan adat. Diskriminasi terhadap perempuan ini memicu timbulnya pergerakan-pergerakan perempuan di awal abad ke-20.

Lahirnya semangat modernisasi di kalangan perempuan, yang mana turut serta di dalamnya mengubah gaya hidup yang lama. Tokoh-tokoh perempuan di separuh pertama abad ke-20 mengkritisi kebiasaan-kebiasaan konvensional yang mereka anggap merugikan posisi perempuan. Upaya-upaya dalam berbagai aspek kemasyarakatan pun dilakukan. Dalam bidang pendidikan, banyak gerakan yang hadir untuk mengupayakan perempuan agar bisa sekolah atau setidaknya mempunyai kemampuan untuk membaca, menulis, dan bisa mengerjakan keteram-pilan-keterampilan yang dapat membuat mereka untuk hidup mandiri.

Mereka diajarkan keterampilan agar bisa menghidupi diri sendiri beserta anakanak mereka tanpa ketergantungan ekonomi terhadap laki-laki. Hal ini untuk mengantisipasi para perempuan yang menjadi janda atau ditinggalkan begitu saja oleh suaminya, sehingga ia kesulitan dalam

${ }^{23}$ Risa Marta Yanti, 'Labirnya Pergerakan Perempuan Minangkabau Pada Awal Abad XX', Jurnal Kafaah, 7.2 (2018) 
memenuhi kebutuhan hidup. Situasi ekonomi yang semakin lama semakin mengandalkan uang, menuntut perempuan untuk bisa bekerja keras guna mendapatkannya. Mereka juga bekerja keras seperti yang dilakukan laki-laki.

Gaya hidup konvensional tentu tidak ditinggalkan atau hilang begitu saja. Kebiasaan-kebiasaan lama tetap ada namun bedanya, setelah memasuki abad ke-20, kebisaan itu bercampur dengan gaya hidup modern. Melalui modernisasi di bidang pendidikan yang juga sejalan dengan pengetahuan mereka di bidang eknomi, perempuan Minangkabau memanfaatkan dua hal tersebut yang kemudian diaplikasikan pada kehidupan mereka sehari-hari.

Perempuan Minangkabau tetaplah seorang ibu rumah tangga yang setelah dibalut dengan modernisasi, mempunyai pengetahuan-pengetahuan baru dalam merawat anak-anak mereka. Sekolah menjadi hal yang penting bagi para orangtua. Mereka menginginkan anak mereka untuk sekolah. Terlepas dari apakah ini hanya mengikuti tren modernisasi atau memang sungguhsungguh ingin menyekolahkan anak mereka. Berikut kutipan yang memperjelas asumsi tersebut.

"Pengetahuan-pengetahuan

lain yang penting untuk perempuan berhubungan dengan persoalan perawatan anak. Ibu rumah tangga modern harus tahu cara merawat anak dengan baik. Anak yang sedang dalam usia sekolah, mutu makanannya harus dijaga dengan baik. Jam tujuh, sarapan sudah harus disiapkan. Nasi dengan telur dan sayur adalah pilihan yang baik. Makan siang dihidangkan setelah anak pulang dari sekolah. Menu yang baik adalah gulai-gulai seperti daging ayam, daging sapi, ikan dan sayursayuran. Untuk makan malam, ibu cukup memanaskan saja gulai-gulai yang ada sehingga tetap sedap untuk di santap." 24

Modernitas membawa kesadaran dalam menjalankan gaya hidup baru di kalangan kaum perempuan. Pendidikan membawa mereka ke jalan arah baru, meng-kritisi gaya hidup konvensional. Kebiasaan poligami laki-laki, tidak bisa dilakukan sesuka hati lagi. Meskipun eksistensi poligami msih banyak dijumpai, namun, perempuan bisa saja memilih untuk diceraikan daripada harus menderita dalam kehidupan pernikahan yang menurut mereka tidak adil.

Hal ini pernah dilakukan oleh Rahmah El Junusiyah. Ia dijodohkan saat berusia 15 tahun. Padahal saat itu belum genap setahun ia menempuh pendidikan di sekolah yang didirikan kakaknya. Suaminya kemudian ingin menikah lagi. Rahmah tidak menyetujui tindakan suaminya ini. Hanya ada dua pilihan bagi Rahmah di sini, menerima atau bercerai. Pilihkan kedua dipilih oleh Rahmah sebagai penolakannya secara tidak langsung atas perilaku poligami suaminya. ${ }^{25}$

Sisi lain modernitas lewat pendidikan ini tidak semuanya bercitra positif. Perempuan tidak bisa sepenuhnya lepas dari apa selama ini dianggap merugikan mereka. Hindia Belanda tidak lepas dari nilai-nilai patriarki. Pengaruh barat menyebarkan virus patriarki dari Eropa. Menyebarnya sisi positif dalam pembaharuan sistem juga dibarengi dengan sisi negatif dalam banyak hal.

Peran gender dalam urusan domestik ala Kebudayaan Indis atau Eropa juga telah lama mengakar seperti dalam adat tradisional Minangkabau. Perempuan

24 Yelda Syafrina, Minangkabau dalam Kemodernan 1900-1942 (Tesis. Universitas Gadjah Mada, 2015), h. 138

25 Nur Janti, 'Kala Ulama Perempuan

Melawan', Historia

$<$ https://historia.id/search/result?keyword=Ulam $\mathrm{a} \% 20$ perempuan\&current $=$ topic\&page $=1>($ acsess 11 Juli 2020) 
masih menjadi tokoh utama yang mana urusan domestik bertumpu kepadanya. Meskipun dalam rumah tangga di awal abad ke-20 hadir asisten rumah tangga yang dipanggi "Bujang", namun, domestifikasi perempuan tetap langgeng dalam bentuknya yang baru. Kemordernan bagi laki-laki adalah lepas dari segala belenggu tradisi. Sebalikya masih ada kaum perempuan yang menjadikan bentuk domestifikasi sebagai bagian dari kemordenan. Perempuan yang mengabdi di rumah adalah suatu hal yang modern, walaupun mereka tidak mengurusi banyak hal secara langsung seperti di dalam gaya hidup konvensional, urusan domestik setelah memasuki abad ke-20, berubah menjadi tren di kalangan perempuan. ${ }^{26}$

\section{KESIMPULAN}

Modernitas bagaimanapun juga tetaplah sebagian besarnya merupakan pengaruh barat. Sebagai bangsa yang dijajah oleh mereka bangsa itu, wajarlah jika banyak terjadi kecurigaan atas setiap hal yang dipengaruhi oleh kebiasaan atau ide mereka. Kata "barat" bagi para orangorang yang memelihara nilai-nilai tradisional adalah suatu bentuk penistaan terhadap tradisi. Sayangnya, nilai-nilai tradisional itu sendiri juga tidak bisa lepas dari kekurangan. Tradisi bisa dipahami sebagai kebiasaan yang terus berulangulang hingga tercipta sebuah peraturan karenanya. Peraturan sudah pasti melibatkan banyak orang untuk melestarikannya. Terlepas dari kebiasaan itu pada awalanya hanyalah milik kalangan tertentu atau sebuah kelompok kecil, yang kemudian menjelma mejadi tradisi yang dilakukan secara masif. Tidak semua tradisi bisa tetap keberadaannya, sebagian akan mengalami pereduksian dari keasliannya. Berubah masa, maka berubah pula sebagian tradisi secara perlahan atau secara cepat. Salah satu perubahan itu, bisa dikarenakan masuknya nilai baru, yang berpotensi membentuk sebuah tradisi baru atau memperbaharui yang lama.

Masuknya nilai baru, bisa juga dipengaruhi oleh munculnya kelompokkelompok kenvensional yang ingin mengadopsi nilai-nilai tersebut. Bagaimanapun nilai barat itu dianggap tidak layak bagi sebagian orang, dan bagaimanapun nilai adat itu dipertahankan kelestariannya, perubahan akan tetap berlangsung, disadari atau tidak, diinginkan atau tidak. Perubahan-perubahan itu salah satunya dapat dilihat dalam gaya hidup modern perempuan Minangkabau. Gaya hidup mereka adalah perpaduan nilai tradisional, Islam, dan barat. Pada akhirnya modernitas tetaplah mempunyai dampak baik dan dampak buruknya. Tujuan perubahan ke arah modern yang pada awalnya untuk mendapatkan sebuah kebaikan, dalam pelaksanaan atau dalam perkembangannya, belum tentu bisa bertahan sesuia dengan tujuan awal. []

26 Yelda Syafrina, Minangkabau dalam Kemodernan 1900-1942 (Tesis. Universitas Gadjah Mada, 2015), h. 181 


\section{DAFTAR PUSTAKA}

Abdullah, Taufik, Adat and Islam; an Exaamination of Conflict in Minangkabau, Southeast Asia Program Publication at Cornell Uniersity, 2 (1966) http://www.jstor.org/stable/33507 $\underline{53}$

Asnan, Gusti, Transportation on the west cost of Sumatra in the nineteeth century, Brill, 158.4 http://www.jstor.org/stable/27867 $\underline{991}$

De Beauvoir, Simone, The Second Sex, ed. by Constance Borde dan Sheila Malovany Chevallier (New York: Vintage Book a Division of Random House Inc, 2010)

Dobbin, Christine, Economic Change in Minangkabau as a Factor in the Rise of the Padri Movement 1784-1830, Southeast Asia Program Publication at Cornell Uniersity, 23 (1977) http://www.jstor.org/stable/33508 $\underline{83}$

Janti, Nur, 'Kala Ulama Perempuan Melawan', Historia, https://historia.id/search/result?key word=Ulama $\% 20$ perempuan\&curre $\underline{\mathrm{nt}=\text { topic\&page }=1}$ (acsess $11 \mathrm{Juli}$ 2020)

Janti, Nur, 'Perjuangan Rohana dalam Pendidikan Kaumnya', Historia, https://historia.id/kultur/articles/p erjuangan-rohana-dalam-pendidikankaumnya-Pdle3 (acsess 11 Juli 2020)

Ju Lan, Thung, Perempuan dan Modernisasi, Jurnal Masyarakat dan Budaya, 17. 1 (2015)

Locher-Scholten, Elsbeth, Women and the Colonial State; Essays on Gender and Modernity in the Netherlands Indies 1900-1942 (Amsterdam: Amsterdam University Press, 2000)

Moenada, Meimunah, Surau dan Modernisasi Pendidikan di Masa Hindia Belanda, Jurnal Sosial Budaya, 8.1 (2011)
Nuryanti, Reni, Perempuan Berselimut Konflik; Perempuan Minangkabau di Masa Dewan Banteng dan PRRI (Yogyakarta: Tiara Wacana, 2011)

Syafrina, Yelda. Tesis. Minangkabau dalam Kemodernan 1900-1942 (Yogyakarta: 2015)

Yanti, Risa Marta, Labirmya Pergerakan Perempuan Minangkabau pada Awal Abad XX, Jurnal Kafaah, 7.2 (2017) http://kafaah.org/index.php/kafaah Lindex

'Pablawan Perempuan dari Tanah Minang', Historia $<\underline{\text { https://historia.id/search/result?k }}$ eyword $=$ Rohana $\% 20$ kudus\&current =topic\&page $=1>($ acsess 11 July 2020) 